6. Finkelstein, J. D., Kyle. W. E., Martin, J. J., and Pick. A.: Activation of cystathionine synthase by adenosylmethionine and adenosylethionine. Biochem. Biophys. Res. Commun., 66: 81 (1975).

7. Finkelstein. J. D.. Mudd, S. H.. Irreverre. F., and Laster, L.: Homocystinuria due to eystathionine synthase deficiency: The mode of inheritance. Science, 146: 785 (1964).

8. Fleisher, L. D., Longhi, R., Tallan. H. H., and Gaull, G. F..: Manuscript in preparation

9. Fleisher, L. D., Tallan, H. H., Beratis, N. G., Hirschhorn, K., and Gaull. G E.: Cystathionine synthase deficiency: Heterozygote defection using cultured skin fibroblasts. Biochem. Biophys. Res. Commun. 55: 38 (1973).

10. Gaull. G. F.. Rassin, D. K.. and Sturman. J. A.: Enzymatic and metabolic studies in homocystinuria: Effects of pyridoxine. Neuropadiatric. 1: 149 $(1969)$.

11. Gaull. G. E., Sturman, J. A., and Schaffner, F.: Homocystinuria due (1) cystathionine synthase deficiency: Enzymatic and ultrastructural studies. J. Pediat.. 84: 381 (1974)

12. Holten. D.. Wicks, W. D., and Kenney, F. T.: Studies on the role of vitimin $B_{4 ;}$ derivatives in regulating tyrosine $\alpha$-ketoglutarate transaminase activity in vitro and in vive. J. Biol. Chem., 242: 1053 (1967).

13. Katunuma. N.. and Kominami. S.: A new enzyme that specifically inactivates apoprotein of pyridoxal enzymes. Biochem. Biophys. Res. Commun., 45. $70(1971)$

14.. Kim. Y. J., and Rosenterg, I., E.: ()n the mechanism of pyridoxine responsive homocystinuria. II. Properties of normal and mutant cystathionine $\beta$ synthase from cultured fibroblasts. Proc. Natl. Acad. Sci. U. S. A., 7l $4821(1974)$.

15. Kimura, H. and Nakagawa. H.: Studies on cystathionine synthase: characteristice of purified rat liver enzyme. J. Biochem. 69: 711 (1971).

16. Litwack, (. ., and Rosenfeld. S.: Coenzyme dissociation, a possible determinant of short half-life of inducible enzymes in mammalian liver. Biochem. Biophys. Res. Commun.. 52: 181 (197.3)

17. Lowry, O. H. Rosebrough. N. J., Farr. A. L.. and Randall. R. J.: Protein measurement with the Folin phenol reagent. J. Biol. Chem.. 19.3: 26.5 (1451).

18. McAlpine, P. J., Hopkinson, D. A.. and Harris. H.: Thermostability studies on the isozymes of human phosphoglucomutase. Ann. Hum. Genet., 34: 61 (1970)

(opyright a) 1977 International Pediatric Rescarch Foundation, Inc
19. Schimke, R. N., Mckusick, V. A., Huang. T., and Pollack. A. D.: Homocystinuria: Studies of 20 families with 38 affected members. J. Amer. Med. Ass. 193:87 (1965)

20. Mudd, S. H. Fdwards, W. A., Locb, P. M., Brown, M. S., and Laster, L.: Homocystinuria due to cystathionine synthase deficiency: The effect of pyridoxine. J, (lin. Invest., 49: 1762 (1971).

21. Mudd, S. H. Finkelstein, J. D., Irreverre, F., and Laster, L.: Homocystinuriat: An enzymatic defect Science, 143: $1443(1964)$

22. Scrutton, M. C.. and Utter, M. F.: Pyruvate carboxylase. 3. Some physical and chemical properties of the highly purified enzyme. J. Biol. Chem., 240: $1(1965)$

23. Singer S and Mason. M. Studies of the in vitro and in vive effects of conjugated stereids and carboxylic acids on hepatic tyrosine transaminase in the rat. Biochim. Biophys. Acta. 146: 4.52 (1967).

24. Tallan, H. H. Pascal, T. A., Schncidman, K., Gillam. B. M., and Gaull G. E.: Homolanthionine svnthesis by human liver cystathionase. Biochem. Biophys. Res. Commun. 43: 3013 (1971).

25. Uhlenderf, B. W.. (onerly, F. B., and Mudd, S. H.: Homocystinuria: Studies in tissue culture. Pediat. Res., 7: 645 (1973).

26. Valentine, R. C., Wrigley, N. G.. Scrutton, M. C., Irias, J. J., and Utter, M. F: Pyruvate carboxylase, VIII. The subunit structure as examined hy clectron microscosy. Biochemistry, 5: 3111 (1966).

27. This study was supported in part by the New York State Department of Mental Hygiene; National Institutes of Health (linical Genetics Center Grant GM19443: National Institutes of Health Grant RR (0)(0)71. Division of Research Resources. General Clinical Research Center Branch; and the Lalor Foundation

28. We thank Doctors M. Pastrana, I. Krasna, and M. Colombo for providing the liver biopsies and Mr. Russell Mallen and Mrs. Susan Sansevero for expert technical assistance Special thanks are given to the " $B$ " family, without whose extraordinary cooperation and interest in research this study could not have been done

29. Requests for reprints should be addressed to: G. F. Gaull. M.D.. Department of Pediatric Research. New York State Institute for Basic Research in Mental Retardation, 1050 Forest Hill Rd.. Staten Island, N. Y. 10314 (USA)

30. Received for publication February 18, 1976

31. Accepted for publication August 20, 1976

\title{
Palmar Crease Variants and Their Clinical Significance: A Study of Newborns at Risk
}

\author{
H. DAR, R. S(HMIDT, AND H. M. NITOWSK Y'2(i)
}

The Rose F. Kennedy Center for Research in Mental Retardation and Human Developme'nt, and Departme'nt of Pediatrics, Albert Einstein College of Medicine of Yeshiva University, Bronx. New' York, USA

\begin{abstract}
Summary
An analysis of palmar crease variants was carried out in a group of "at risk" newborns, without any evident congenital anomalies. This group consisted of 108 prematures, 74 infants who were small for gestational age, 62 newborns with history of gestational complications, and 46 newborns with a history of intrauterine methadone exposure.

A system of classification was developed based on observations of 500 normal newborns as control subjects, 466 normal mothers, and 200 normal children. The palmar crease variants can be divided into four main groups, schematically presented as normal variants, simian crease and its variants, Sydney line and its variants, and another group of unusual variants which do not fit into the other groups. A study of these groups revealed that familial components, race, sex, and age are factors that can
\end{abstract}

influence the expression of palmar crease patterns. There is an increased frequency of abnormal creases in each of the groups of "at risk" newborns. Moreover, there is an apparent association of interrupted transverse creases and intrauterine methadone exposure.

\section{Speculation}

Our findings suggest that examination of palmar creases and the demonstration of variant patterns may provide a useful, objective indicator of possible abnormal fetal development. Since it is important to utilize a standard scheme in routine newborn examination, both to identify palmar crease variants and to establish a baseline for comparative studies, a system for classification of palmar creases is presented. 
The association between unusual palmar creases and various congenital disorders has been reported by many authors. These disorders may be genetic in origin $(8,18)$, or may be caused by environmental factors such as viruses $(1.19)$ or a variety of teratogenic agents $(9,13,14)$. Although it has been shown that a considerable variability in palmar creases exists in the population (2). most studies have dealt only with the simian crease $(5,6)$ or with the simian crease and its variants $(9,16)$. Purvis Smith (16) drew attention to the Sydney line variant which seems to have a clinical significance in certain disorders.

Another previously undescribed palmar crease variant was reported with the congenital alcohol syndrome (11). Johnson and $O$ ritz (10) concluded that "unusual palm creases are associated with unusual children." These and other studies suggest that a variety of palmar crease alterations may be indicative of intrauterine disturbances occurring early in pregnancy (thus providing a tool for definition of high risk groups). To determine the usefulness of this sign, a diagnostic scheme and a system of classification was developed and applied to various groups of normal and "at risk" newborns who did not show gross congenital anomalies.

\section{MATERIALS AND METHODS}

The study was conducted in the newborn nurseries of the Bronx Municipal Hospital Center. New York, between September 1973 and May 1975, and was carried out as an addition to the routine clinical evaluation during this period. All palmar crease patterns were recorded from direct visual examination by the same observer (Dr. H. Dar).

Additional groups of normal children, aged $3-8$ years, were seen at two parochial schools, a nursery school and a well child clinic.

A system of classification was developed initially based on observations of normal subjects, including 500 full term newborns and 200 children. Some of the variants which were found only in the high risk groups and in children with Down's syndrome (4) were added later. This system includes variants described previously $(2,9-11)$ as well as variants not described before. Only the main transverse creases were classified. The palmer crease patterns can be classified into four main groups: $A$, patterns that are classified as normal $\left(A_{1}, A_{2}, A_{3}\right)$ (Fig. 1a); B. typical simian crease $\left(B_{0}, B_{1}\right)$ and variants $\left(B_{2}-B_{4}\right)(F i g .1 b)$; $C$, sydney line $\left(C_{11}\right)$ and variants $\left(C_{1}-C_{3}\right)$ (Fig. $\left.I^{2}\right)$; D. other unusual variants that did not fit into the other groups $\left(D_{1}-D_{4}\right)$ (Fig. 1d). The palms of 990 newborns were examined and the palmar crease patterns categorized according to the scheme in Figure 1. Since the medical records were reviewed after inspection of the crease pattern, the palmar crease evaluation was carried out independently of any clinical assessment.

Although all the newborn infants in the nursery were examined and their palmar crease variants recorded, only singleton newborns who fulfilled the criteria of one of the following groups were included in this study.

\section{CONTROL GROUP}

This was a group which consisted of 500 normal full term newborns with birth weight of $2.500 \mathrm{~g}$ or more, born consecutively in the hospital between September 1974 and April 1975. These infants had no evident congenital anomalies and no history of gestational or perinatal complications.

\section{MOTHERS}

Whenever possible, the palmar crease patterns of the mothers were recorded and categorized in the same way.

\section{NF:WBORNS AT RISK}

The majority were seen in the neonatal intensive care unit. Newborns with evident congenital malformations were excluded. Four groups were studied.
Group 1: Premature Infants. This group consisted of 108 premature newborns admitted to the intensive care unit with a gestational age of 36 weeks or less, as determined by dates, physical and neurological examinations.

Group 2: Small for Gestational Age Infants. This group consisted of 74 newborns with a birth weight which was less than the 10th percentile for their gestational age (12). The gestational age ranged from 31 to 43 weeks.

Group 3: Infants with Gestational Complications. This group consisted of 62 newborns. The complications during pregnancy were mostly hypertension ( 31 newborns), but also included toxemia, syphilis, hypothyroidism. hepatitis, and others. Newborns of diabetic mothers were excluded from this study.

Group 4: Newborns with Intrauterine Methadone Exposure. An additional 46 newborns of mothers who were on methadone maintenance during pregnancy were included in this group. A few of the mothers were known users of other drugs as well, mainly heroin. Five of the infants were premature and six were small for dates, but since the mothers had been on methadone maintenance they were retained in this subgroup.

The characteristics of the study population in regard to sex and race are shown in Tables 1 and 2 .

\section{RESULTS}

\section{STUDIES OF NORMAL INFANTS AND (HILDREN}

Sex and Racial Differences. Since our study population includes white as well as black newborns, an examination was carried out for possible racial as well as sex differences among the normal newborn control group (Table 2). Statistically significant differences between whites and blacks are observed in two instances. A higher incidence of the Sydney line $(C)$ is seen among white females, and the unusual variants which fall into the D group (Fig. 1d) occur with higher incidence among black females, the differences being statistically significant in each case $\left(\chi^{2}=10.80 . P<0.005 ; \chi^{2}=5.12 . P<0.025\right.$. respectively $)$.

No significant racial or sex differences are found in relation to the simian crease and its variants.

Age Differences. Since the incidence of the Sydney line in our newborn population, especially in females, appears to be higher than in previous reports $(2,15,16)$, a group of 200 normal children aged $3-8$ years with a similar racial composition was studied. Although $9.2 \%$ of palms of normal female newborns have variants classified as Sydney lines, only $1.5 \%$ of the palms of older girls show this feature (Fig. $1 c, C_{0}$ ). The pattern classified as $A_{2-1}$ (Fig. 1), in which the proximal transverse crease extends beyond the midline of the fifth finger but does not cross the whole palm. occurs in $11 \%$ of the palms of older girls, but only in $0.4 \%$ of the palms of female newborns. The same trend is seen in the males of the two age groups. Since the frequency of the $A_{2-1}$ pattern plus that of the Sydney line is about the same in the two age groups, it appears that some of the palms classified as having a Sydney line at birth, develop a palmar crease pattern that resembles the $A_{2-1}$ pattern later in childhood. Debrunner (7) reported a higher incidence of palmar crease variants which, by description, might be classified as the Sydney line, in a large group of fetuses and newborns as compared with adults. A longitudinal study is needed to clarify the basis for the difference in frequency of the Sydney line in newborns and in older children. Without such data, the use of a control group unmatched for age for the study of frequency of palmar crease variants may lead to erroneous conclusions. No significant differences were found in regard to the frequency of the other variants.

\section{COMPARISON OF PALMAR CREASE VARIANTS OF MOTHERS AND THEIR INFANTS}

In an attempt to obtain some information concerning intrafamilial similarities in palmar crease patterns, studies were carried out on 466 mothers of newborns examined. In the majority 

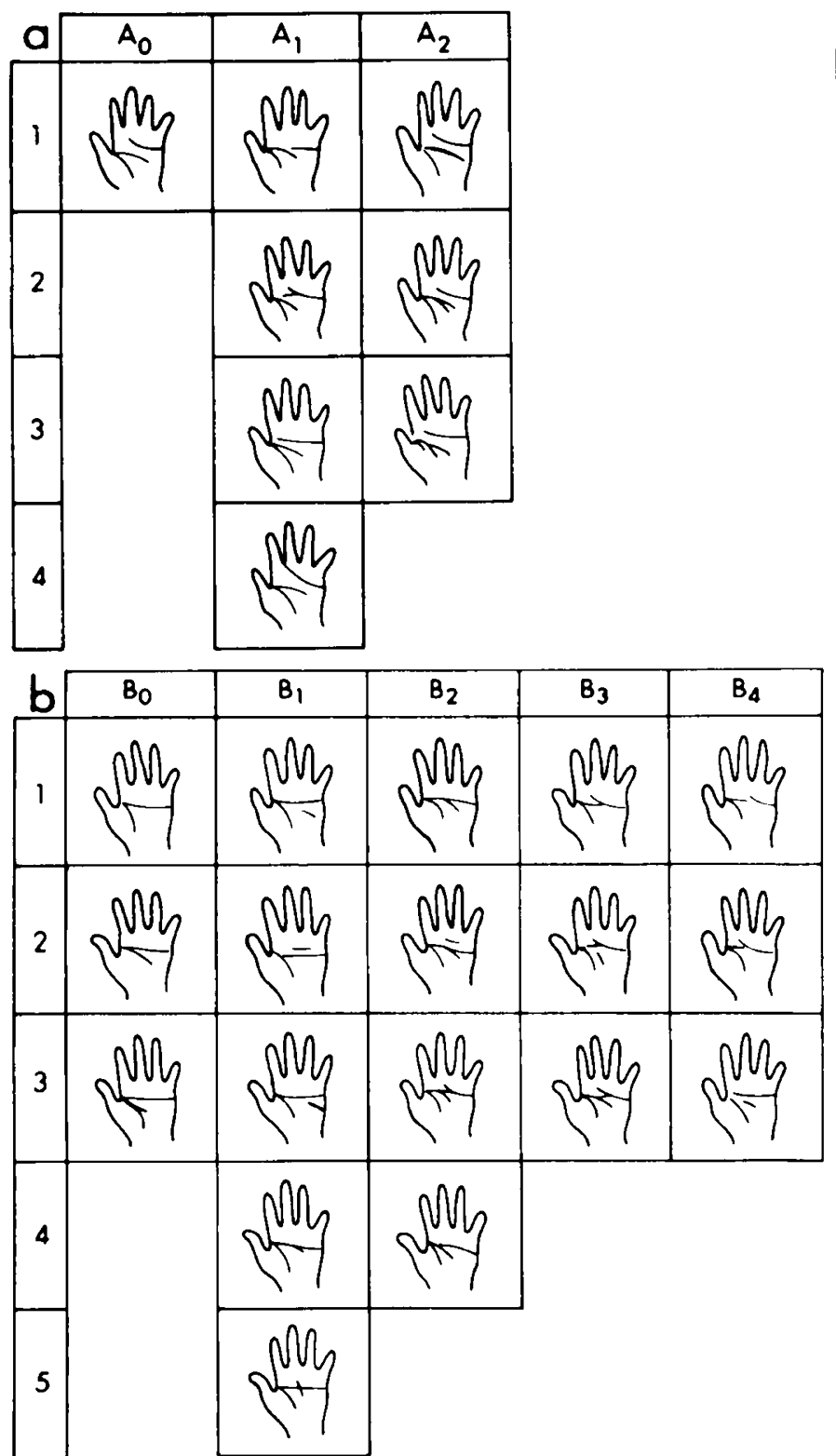
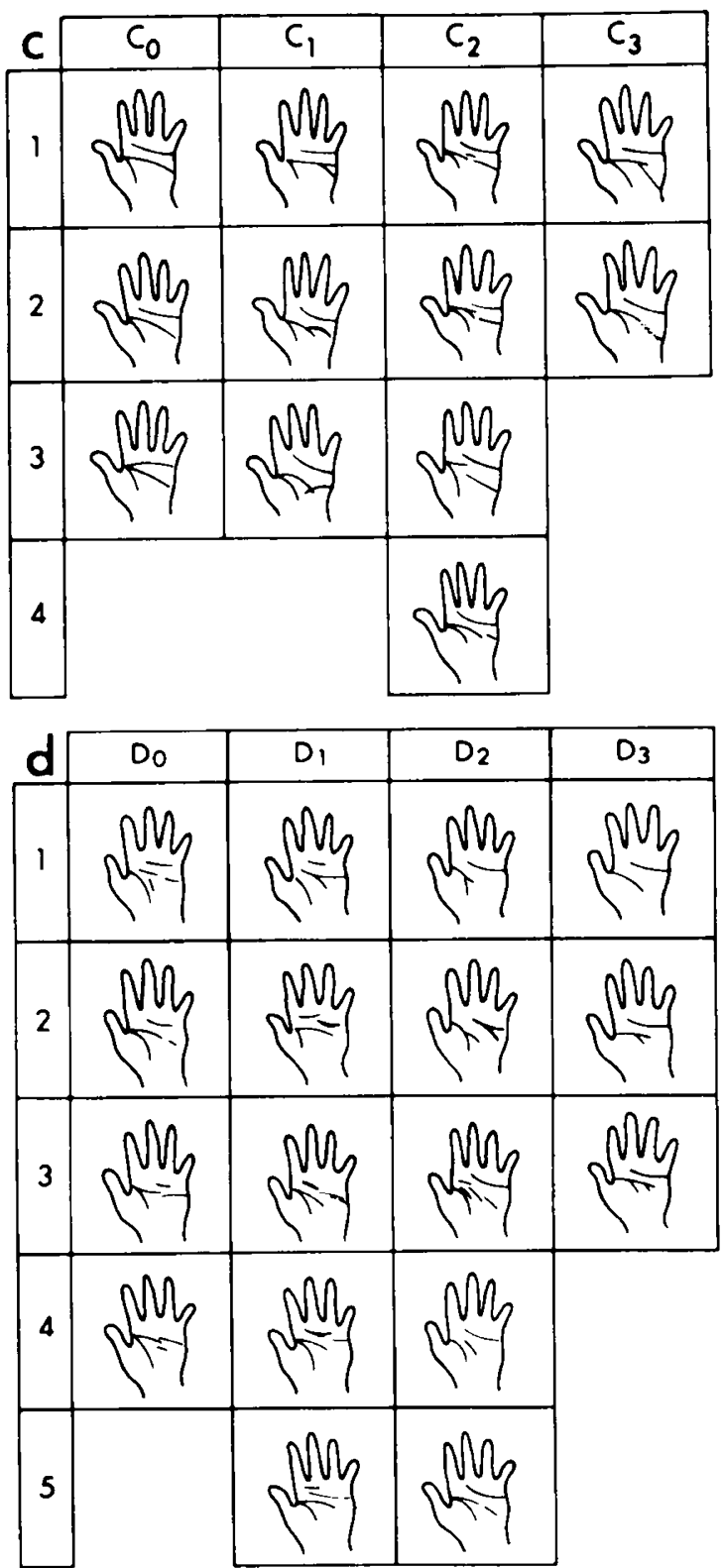

Fig. 1. Palmar crease variants based on 200 normal children (100 males and 100 females) and 500 normal newborns (260 males and 240 females). $a$ : "normal" palmar creases and variants (A). $A_{10}$, typical normal palmar creases - the most prevalent type, found in $94 \%$ of the normal individuals studied. $A_{1}$, variants of the distal transverse crease. $A_{2}$, variants of the proximal transverse crease. $b$ : simian crease $\left(B-B_{0}, B_{1}\right)$ and its variants $\left(B_{v}-B_{2}\right.$, $\left.B_{3}, B_{4}\right), B_{1}$. typical simian crease. Uninterrupted single line crosses the palm. (Variant $B_{0-2}$ was not found among the normal individuals studied, although it was found in $3 \%$ of palms of 100 children with Down's syndrome (4).) $B_{1}$, typical simian crease with rudimentary second transverse crease. (Variant $B_{1+4}$ was found in $4 \%$ of patients with Down's syndrome but not in normal individuals.) $B_{2}$, uninterrupted line crosses the palm; the proximal transverse crease is present. $B_{3}$, continuous horizontal line formed by a connection between the proximal and distal transverse lines. (Variant $B_{3-1}$ was not found in normal individuals; however, it was found in $4 \%$ of the palms of 100 children with Down's syndrome.) $B_{4}$, slightly interrupted horizontal line crosses the palm. Sometimes a rudimentary proximal transverse crease is found. $c$ : Sydney line $\left(C^{-}\right)$and its variants $\left(C_{v}-C_{1}\right.$. $\left.\mathrm{C}_{2}, \mathrm{C}_{3}\right), \mathrm{C}_{0}$, uninterrupted proximal transverse line extends to the ulnar border of the palm. It is wider than two epidermal ridges in the typical form $\left(C_{i-1}\right)$ or it becomes thinner toward the ulnar border line of the palm $\left(C_{0.2}\right)$. (Variant $C_{10: 3}$ was not found in normal individuals. but was found in $2 \mathrm{~m}$ of the palms of children with Down's syndrome.) $C_{1}$, a branched proximal transverse line extends to the ulnar border of the palm. $C_{2}$, an interrupted proximal transverse crease extends to the ulnar border of the palm. $C_{3}$, a broken proximal transverse crease extends to the ulnar border of the palm. $d$ : other unusual palmar creases (D). $D_{0}$, interrupted and partially developed distal and proximal transverse creases. (Variant $D_{0-3}$ was not found in normal individuals but was found in $4 \%$ of newborns exposed to methadone during fetal life.) $D_{1}$, interrupted distal palmar creases. $D_{2}$, unusual proximal transverse crease. $D_{3}$. undeveloped thenar crease. (Variant $D_{3-1}$ was not found among normal individuals but was found in $1 \%$ of children with Down's syndrome.)

of cases, the mothers had normal newborn babies (control group). A small group of twins and prematures and their mothers was included as well. The results are summarized in Table 3. The overall incidence of newborns with simian creases and their variants $\left(B\right.$ and $B_{v}$ ) was $7.9 \%$. However, 5 of $21(23.8 \%)$ babies born to mothers with simian creases or variants showed this feature. This difference is statistically significant $\left(\chi^{2}=6.12 ; P\right.$
$<0.025)$. A familial component is similarly seen for each of the groups of palmar crease variants.

\section{"AT RISK" NEWBORNS (TABLE 4)}

Group 1: Premature Infants. This group shows a significantly higher incidence of simian crease variants $\left(B_{v}\right)$, although the 
Table 1. Composition of study population according to sex and race

\begin{tabular}{|c|c|c|c|c|c|c|c|}
\hline Sex & Race & $\begin{array}{l}\text { Full term new- } \\
\text { borns }\end{array}$ & $\begin{array}{l}\text { Normal chil- } \\
\text { dren }\end{array}$ & Prematures & $\begin{array}{l}\text { Small for gesta- } \\
\text { tional age }\end{array}$ & $\begin{array}{l}\text { Intrauterine meth- } \\
\text { adone exposure }\end{array}$ & $\begin{array}{l}\text { Gestational compli- } \\
\text { cations }\end{array}$ \\
\hline \multirow[t]{3}{*}{ Male } & White & 160 & 78 & 29 & 16 & 10 & 19 \\
\hline & Black & 100 & 22 & 20 & 13 & 18 & 7 \\
\hline & Subtotal & 260 & 100 & 49 & 29 & 28 & 26 \\
\hline \multirow[t]{4}{*}{ Female } & White & 140 & 65 & 34 & 26 & 9 & 21 \\
\hline & Black & 100 & 35 & 25 & 19 & 9 & 15 \\
\hline & Subtotal & 240 & 100 & 59 & 45 & 18 & 36 \\
\hline & Total & 500 & 200 & 108 & 74 & 46 & 62 \\
\hline
\end{tabular}

Table 2. Distribution (percentage) of palmar crease patterns in palms of 500 normal newborns according to sex and race ${ }^{1}$

\begin{tabular}{|c|c|c|c|c|c|c|c|c|c|}
\hline \multirow{2}{*}{$\begin{array}{l}\text { Palmar } \\
\text { crease } \\
\text { pattern' }\end{array}$} & \multicolumn{3}{|c|}{ Males } & \multicolumn{3}{|c|}{ Females } & \multicolumn{3}{|c|}{ Both sexes } \\
\hline & $\begin{array}{c}\text { White } \\
(n=160)\end{array}$ & $\begin{array}{c}\text { Black } \\
(n=100)\end{array}$ & $\begin{array}{c}\text { Total } \\
(n=260)\end{array}$ & $\begin{array}{c}\text { White } \\
(n=140)\end{array}$ & $\begin{array}{c}\text { Black } \\
(n=10())\end{array}$ & $\begin{array}{c}\text { Total } \\
(n=240)\end{array}$ & $\begin{array}{c}\text { White } \\
(n=300)\end{array}$ & $\begin{array}{c}\text { Black } \\
(n=200)\end{array}$ & $\begin{array}{c}\text { Total } \\
(n=500)\end{array}$ \\
\hline A & 80.5 & 87.5 & 8.3 .4 & 73.2 & 75.0 & 74.0 & 77.0 & 81.2 & 78.8 \\
\hline B & 2.8 & 0.5 & 1.9 & 0.7 & 1.5 & 10 & 1.8 & 1.0 & 1.5 \\
\hline $\mathrm{B}_{\mathrm{v}}$ & 2.8 & 2.0 & 2.5 & 3.2 & 2.5 & 2.9 & 3.0 & 2.3 & 2.7 \\
\hline C & 4.9 & 3.0 & 4.3 & $12.5^{2}$ & 4.5 & 9.2 & $8.5^{2}$ & 3.8 & 6.6 \\
\hline$C_{v}$ & 7.8 & 4.5 & 6.5 & 8.2 & 10.5 & 8.9 & 8.0 & 7.5 & 7.7 \\
\hline D & 1.2 & 2.5 & 1.5 & 2.2 & $6.0^{3}$ & 4.0 & 1.7 & 4.2 & 2.7 \\
\hline
\end{tabular}

${ }^{1}$ For description of patterns, see Figure $1, a-d$.

${ }^{2}$ Racial differences are statistically significant $\left(\chi^{2}=0.5 \%\right)$

${ }^{3}$ Racial differences are statistically significant $\left(\chi^{2}=2.5 \%\right)$.

Table 3. Palmar crease variants in 466 newborns and their mothers ${ }^{1}$

Crease patterns in newborns

\begin{tabular}{|c|c|c|c|c|c|c|c|c|}
\hline $\begin{array}{c}\text { Crease pat- } \\
\text { terns }\end{array}$ & A & B & $\mathrm{B}_{\mathrm{v}}$ & $c$ & $C_{v}$ & $D$ & $\begin{array}{l}\text { Bilat- } \\
\text { eral } \\
\text { forms? }\end{array}$ & $\begin{array}{c}\text { Total } \\
\text { (mothers) }\end{array}$ \\
\hline \multicolumn{9}{|l|}{ Mothers } \\
\hline A & 25.3 & 10 & 15 & 36 & 40 & $y$ & 11 & 374 \\
\hline B & 3 & & 1 & & & & & 4 \\
\hline B. & 8 & 1 & 3 & 2 & 3 & & & 17 \\
\hline$C^{\prime}$ & & & & 3 & 1 & & & 4 \\
\hline$C_{v}$ & 8 & & 1 & 1 & 6 & & 1 & 17 \\
\hline D & 23 & 4 & 2 & 3 & 4 & 9 & 2 & 47 \\
\hline $\begin{array}{r}\text { Bilateral } \\
\text { forms }{ }^{2}\end{array}$ & 2 & & & & 1 & & & 3 \\
\hline $\begin{array}{l}\text { Total } \\
\text { (newborns) }\end{array}$ & 297 & 15 & 22 & 45 & 55 & 18 & 14 & 466 \\
\hline
\end{tabular}

' For description of patterns, see Figure $1, a-d$

${ }^{2}$ Number of subjects who showed lack of concordance of the palmar crease pattern in the two palms.

overall incidence of abnormal creases is not significantly different compared with control subjects.

Group 2: Simall for Gestational Age Infants. There is a significantly increased incidence of simian crease variants $\left(B_{v}\right)$ as well as variants of Sydney lines $\left(C_{v}\right)$ among infants who are small for gestational age. However, the increased incidence of Sydney lines appears to reflect the excess number of white females who, in the control group, demonstrate a higher frequency of this pattern.

Group 3: Newborns with a History of Gestational Complications. This group shows an increased frequency of abnormal creases, but the difference from control subjects is not statistically significant

Group 4: Newborns of Mothers on Methadone Maintenance. A significantly higher frequency of abnormal creases is found among newborns of mothers on methadone maintenance. The differences are significant for variants of the Sydney line $\left(C_{v}\right)$ in female newborns and most striking for variants classified in the D group in male newborns (Fig. Id).

Further analysis utilizing our detailed diagnostic scheme revealed that 11 out of 12 palms with $D$ variants have interrupted transverse creases. The most striking variants are $D_{1-2}$ and $D_{1-1}$, which occur bilaterally in four males (three whites and one black). Among the 500 normal newborns, only one palm shows the $D_{1-4}$ variant. The palmar crease variant $D_{1-4}$ in a newborn of a mother on methadone is shown in Figure 2. Of eight palms with Sydney line variants $\left(C_{v}\right)$ in this group. five have an interrupted proximal transverse line. (Variants $C_{1-3}, C_{2-3}, C_{2-4}$ in Fig. lc). Thus, 16 palms of 11 new borns of mothers on methadone maintenance out of 46 newborns in this group $(23.9 \%)$ show interrupted transverse creases as compared with $6.6 \%$ of the control group. This difference is highly significant $\left(X^{2}=17.05\right.$; $P<0.005)$. Following this finding, 13 newborns of heroinaddicted mothers who were not on methadone were examined. None of these infants show this feature.

\section{DISCUSSION}

The association of unusual palmar creases, especially the simian crease and its variants, with congenital malformations is well documented (7). Our main interest, however, was to study the prevalence of unusual palmar creases in newborns of mothers with complications of gestation. A higher incidence of abnormal palmar crease patterns in these infants might be the only visible evidence at birth for early intrauterine disturbances. The predictive value of these abnormalities remains to be studied.

Davies (5) found a higher incidence of simian creases in a newborn population as compared with school children. This was not surprising, since cases of stillbirths, neonatal deaths, and newborns with congenital malformations were included in this report. In the same study an increased proportion of low birth weight newborns (including small for gestational age) was found among newborns with simian creases. Similar findings were shown in our preliminary study (3) in which a significantly higher 
Table 4. Relative distribution of palmar crease patterns in study population'

\begin{tabular}{|c|c|c|c|c|c|c|c|c|c|c|c|c|}
\hline \multirow{2}{*}{$\begin{array}{l}\text { Palmar } \\
\text { crease } \\
\text { pattern }\end{array}$} & \multicolumn{2}{|c|}{ Normal newborns } & \multicolumn{2}{|c|}{ Normal children } & \multicolumn{2}{|c|}{ Premature } & \multicolumn{2}{|c|}{$\begin{array}{c}\text { Gestational compli- } \\
\text { cations }\end{array}$} & \multicolumn{2}{|c|}{$\begin{array}{l}\text { Small for gestational } \\
\text { age }\end{array}$} & \multicolumn{2}{|c|}{$\begin{array}{l}\text { Intrauterine metha- } \\
\text { done exposure }\end{array}$} \\
\hline & $\begin{array}{c}\mathrm{M} \\
(520)^{2}\end{array}$ & $\begin{array}{c}F \\
(480)\end{array}$ & $\begin{array}{c}M \\
(200)\end{array}$ & $\underset{(200)}{F}$ & $\begin{array}{c}M \\
(98)\end{array}$ & $\begin{array}{c}F \\
(118)\end{array}$ & $\begin{array}{c}M \\
(52)\end{array}$ & $\begin{array}{c}F \\
(72)\end{array}$ & $\begin{array}{c}M \\
(58) \\
\end{array}$ & $\begin{array}{c}F \\
(9(0)\end{array}$ & $\begin{array}{c}M \\
(56)\end{array}$ & $\begin{array}{c}F \\
(36)\end{array}$ \\
\hline A & $83.4^{3}$ & 74.0 & 89.0 & 90.5 & 77.6 & 76.3 & 73.2 & 68.0 & 81.0 & 52.3 & 53.6 & 72.2 \\
\hline B & 1.9 & 1.0 & 1.0 & 1.0 & 2.0 & 3.4 & 1.9 & 1.4 & () & 0 & 5.4 & 2.8 \\
\hline $\mathrm{B}_{\mathrm{v}}$ & 2.5 & 2.9 & 3.0 & 2.0 & $7.1^{4}$ & 4.2 & 3.8 & 6.9 & 5.8 & $10.0^{\circ}$ & 7.1 & 2.8 \\
\hline $\mathrm{C}$ & 4.2 & 9.2 & 1.5 & 1.5 & 8.2 & 11.0 & 9.6 & 1.5 .3 & 10.3 & 14.4 & 7.1 & 8.3 \\
\hline$C_{1}$ & 6.5 & 8.9 & 2.0 & 3.5 & 4.1 & 3.4 & 11.5 & 4.2 & 3.4 & $18.9^{5}$ & 5.4 & $13.9^{4}$ \\
\hline$D$ & 1.5 & 4.0 & 3.5 & 1.5 & 1.0 & 1.7 & 0 & 4.2 & 0 & 4.4 & $21.4^{i}$ & 0 \\
\hline
\end{tabular}

${ }^{1} \mathrm{M}$ and $\mathrm{F}$ refer to male and female, respectively.

2 Refers to number of palms.

${ }^{3}$ Results are expressed as a percentage of palms in subgroup.

${ }^{4}$ Difference significant at $P=0.025$.

s Difference significant at $P=0.005$.

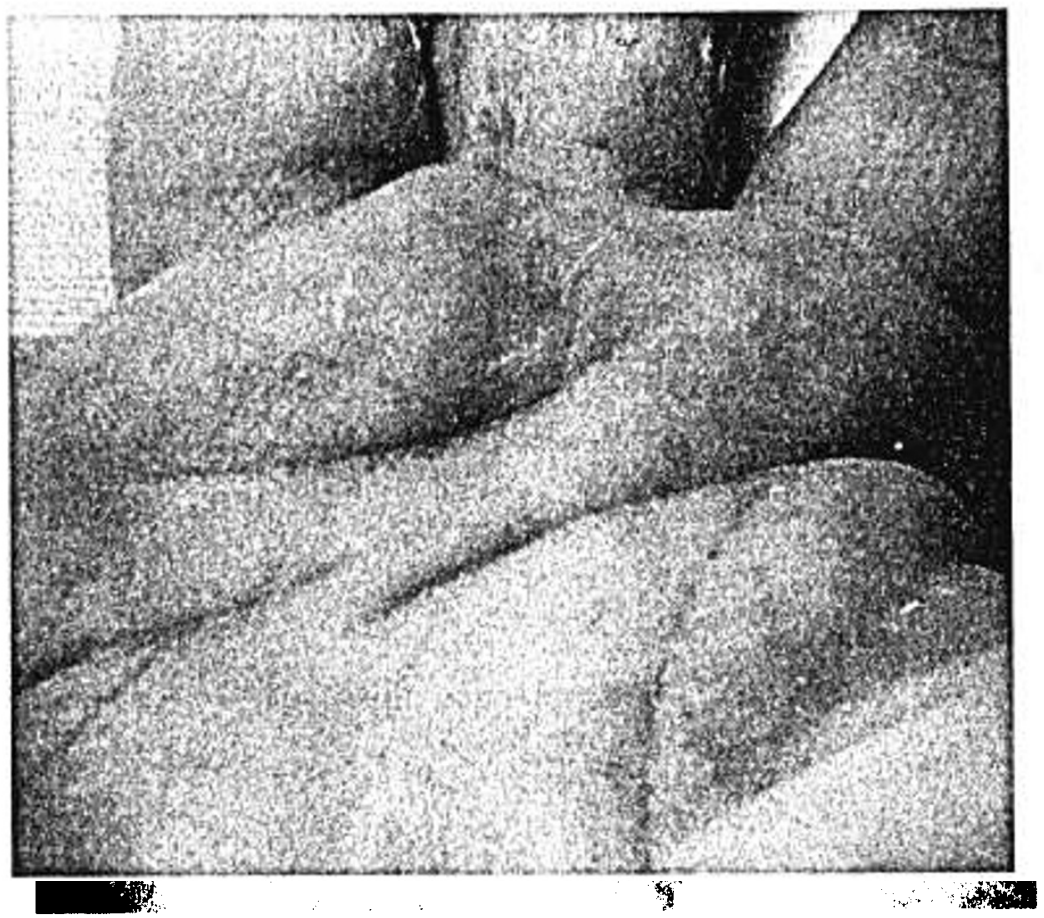

Fig. 2. Right hand of an infant whose mother has a history of methadone intake during pregnancy. Note interrupted transverse creases (D ${ }_{1-1}$, Fig. 1d) (23).

frequency of simian creases and variants was found among low birth weight newborns $(<2,500 \mathrm{~g})$ without evident congenital malformations, compared with normal weight newborns.

In the present study a system of classification of palmar crease pattern was devised. The detailed breakdown of the palmar crease subtypes illustrated in Figure 1 is suggested as a baseline for further investigations of palmar crease patterns. Based on findings in 500 normal newborns, 466 of their mothers, and 200 normal children, correlations were observed between the pattern in the infant or child and maternal pattern, race, sex, and age. All these factors should be taken into consideration in studies of palmar crease variants.

Premature infants were chosen for the study of newborns at risk on the premise that in some of these infants intrauterine disturbances, leading ultimately to the birth of a premature baby, might also cause alterations in the creases. This was confirmed by the significantly increased incidence of simian crease variants found in this group.

Since a higher frequency of congenital malformations was reported among small for gestational age newborns (19), an even higher incidence of palmar crease alterations could be anticipated in this group. Our results, as shown in Tables 1 and 2 , confirm this expectation. A tendency to higher frequency of abnormal creases was also demonstrated in group 3 infants with gestational complications, indicating that some of the complications may result in an insult to the fetus early in fetal life. An interesting finding was the apparent association of interrupted transverse creases and intraterine exposure to methadone. An association of a characteristic palmar crease variant and a specific teratogen was described in babies with the congenital alcohol syndrome (11).

The findings in this study suggest that examination of palmar crease patterns may provide a useful, objective criterion for fetal developmental abnormalities. It is recommended that a standard scheme be utilized to identify and classify palmar crease variants as part of the routine newborn examination. Such a scheme may serve as a baseline for comparative studies of palmar crease variants.

\section{CONCLUSION}

Based on a standard scheme for classification of palmar crease patterns, we have found that groups of newborn infants at risk as 
a result of a suspected early intrauterine insult show an increased frequency of abnormal creases. There is an association between interrupted transverse creases and intrauterine methadone exposure. Race, sex, age, and intrafamilial concordance are some of the variables that should be considered in evaluating palmar crease patterns.

\section{REFERENCES AND NOTES}

1. Achs, R., Harper, R. G., and Siegel, M: Unusual dermatoglyphic findings associated with rubella embryopathy. New Engl. J. Med., 274: 148 (1966).

2. Alter, M.: Variation in palmar creases. Amer. J. Dis. Child.., 20: 424 (1970).

3. Dar, H. Carney, F. C., and Winter. S. T.: Dermatoglyphics and the simian crease in infants of low birth weight: A pilot study. Acta Paediat. Scand, 60: $479(1971)$

4. Dar, H., and Schmidt, R.: A topographic approach for analysis of palm crease variants. J. Med. Genet. 13:310 (1976)

5. Davies, P. A., and Smallpeice, V.: The single transverse palmar crease in infants and children. Dev. Med. Child. Neurol., 5: 491 (1963).

6. Davies, P. A., and Smallpeice, V.: Sex and the single transverse palmar crease in newborn singletons. Dev. Med. Child. Neurol., 8: 729 (1966).

7. Debrunner, I. M.: Morphologischer Bauplan der ballenbedingten Handfurchen bei Primaten. Z. Anthropol. Morphol., 47: 187 (1956).

8. Holt. S. B.: The Genetics of Dermal Ridges (Charles C Thomas, Springfield. IIl., 1968).

9. Hook, E. B., Bonenfast, R. C. A., Powers, M. L., Greenberg. M., and Shapiro, L. R.: The human simian crease and its variants $-A$ model for investigation of serious congenital malformations. Birth Def., 10(7): 7 $(1974)$.

10. Johnson, C. F., and Opitz, E.: Unusual palm creases and unusual children. The Sydney line and "type $C$ " palmar lines and their clinical significance in a child development clinic. Clin. Pediat., 12: 101 (1973).

11. Jones, K. L., Smith, D. W.. Ulleland, C. N., and Streissguth, A. P.: Pattern of malformation in offspring of alcoholic mothers. Lancet, $1: 1267$ (1973).

12. Lubchenco, L. O., Hansman, C., and Boyd, E.: Intrauterine growth in length and head circumference as estimated from live births at gestational ages from 26 to 42 weeks. Pediatrics, 37: 403 (1966).

13. Milunsky, A., Great, J. W., and Gaynor, M. F.: Methotrexate-induced congenital malformations. J. Pediat., 72: 790 (1968)

14. Pfeiffer, R. A., and ZuBerge. U. S.: Untersuchungen zur Frage der Handleis- ten und Furchen bei Extremitaeten Missbildungen. Menchl. Venerb. Konstitutionlehre, 37: 677 (1964)

15. Plato, C. C.. Cereghino, J. J., and Steinberg, F. S. Palmar dermatoglyphics of Down's syndrome. Pediat. Res., 7: 111 (1973).

16. Purvis-Smith, S. G.. and Menser, M. A.: Dermatoglyphic defects and rubella teratogenesis. J. Amer. Med. Ass., 209: 1865 (1968).

17. Rosner, F., Steinberg, F. S., and Sprigge, H. A.: Dermatoglyphic patterns in patients with selected neurological disorders. Amer. J. Med. Sci., 254: 134 (1967).

18. Uchida, I. A., Patau, K., and Smith, D. W.: Dermal patterns of 18 and $D_{1}$ trisomies. Amer. J. Hum. Genet., 14: 345 (1962).

19. Van den Berg. B. J., and Yerushalmy, J.: The relationship of the rate of intrauterine growth of infants of low birth weight to mortality, and congenital anomalies. J. Pediat., 69: 531 (1966).

20. Vrydagh-Laoureux, S.: Le pli palmaire transverse dans une population belge normale et chez 86 mongoliens. Bull. Soc. Roy. Belge Anthrop. Prehist. 78: 237 (1967)

21. Wright, H. T., Parker, C. E., and Mavalwala, J.: Unusual dermatoglyphic findings associated with cytomegalic inclusion disease of infancy. Calif. Med., 116: 19 (1972)

22. Informed consent was obtained from the mother before obtaining palm print patterns on newborn infants or older children, in accord with the procedure approved by the Committee on Clinical Investigation of the Bronx Municipal Hospital Center.

23. A signed release was obtained from the mother to permit a photograph to be obtained and published of this infant's hand, in accord with established policy at this institution.

24. We wish to thank Dr. L. M. Gartner, Dr. S. Kandall, and Mrs. M. Winters and Miss E. Caputo and other members of the staff of the Neonatalogy Division at the Bronx Municipal Hospital Center for their cooperation. We also wish to acknowledge the assistance and cooperation of the principals and teachers of the St. Helena and Philip and James Schools, the Memorial Nursery School, and Dr. K. S. Lobach and the staff of the Comprehensive Child Care Program.

25. Submitted by $H$. Dar in partial fulfillment of the requirements for the $P h$ D. degree at the Technion Institute of Technology. Haifa, Israel. Present address: Genetic Unit, Rothschild Hospital, Haifa, Israel.

26. Requests for reprints should be addressed to: H. M. Nitowsky, M.D., Department of Pediatrics. Albert Einstein College of Medicine, Bronx, N. Y. 10461 (USA).

27. Received for publication February 18,1976

28. Accepted for publication August 6, 1976 premature infants small for gestational age glucagon glucose

(SGA) infants insulin

\title{
Effects of Oral Glucose and Protein Load on Plasma Glucagon and Insulin Concentrations in Small for Gestational Age Infants
}

\author{
B. L. SALLE AND A. RUITON-UGLIENGO(31)
}

Neonatal Department, Hôpital E. Herriot, Lyon, France

\section{Summary}

This paper reports portal and peripheral blood glucose, insulin, and glucagon levels in small for gestational age (SGA) and appropriate for gestational age ( $A$ GA) newborns during the first $48 \mathrm{hr}$ of life. These parameters were studied after an oral glucose and protein load (1 $\mathrm{g} / \mathrm{kg}$ of each) after a 4-hr fast.

In $A G A$ and SGA infants, mean fasting blood glucose level was significantly higher in the portal vein than in the aorta $(P<$ $0.05)$. After the load, mean blood glucose level rose significantly in both vessels.
The mean fasting plasma insulin level was low and was similar in both vessels. After the load in the AGA group mean plasma insulin level rose significantly at $45 \mathrm{~min}$ in both vessels $(P<$ $0.05)(52.1 \pm 37.2 \mu \mathrm{U} / \mathrm{ml}$ in aorta and $91.8 \pm 75.3 \mu \mathrm{U} / \mathrm{ml}$ in portal vein). In the SGA group, the insulin response was minimal in the aorta and in the portal vein; the increase was significant only in the portal vein $(P<0.05)$ at $180 \mathrm{~min}(47.1 \pm 25.3$ $\boldsymbol{\mu} \mathbf{U} / \mathbf{m l})$.

The mean fasting plasma glucagon level was higher in the portal vein than in the aorta in both groups $(P<\mathbf{0 . 0 5})$. After the load in AGA infants plasma glucagon rose significantly from 